\title{
PERANCANGAN PROGRAM GAME PC HACK \& SLASH BERBASIS MULTIMEDIA MENGGUNAKAN UNITY 3D
}

Conference Paper · October 2016

\section{CITATIONS}

0

1 author:

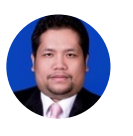

Darmawan Napitupulu

Indonesian Institute of Sciences

27 PUBLICATIONS 22 CITATIONS

SEE PROFILE
READS

19

Some of the authors of this publication are also working on these related projects: 
Pusat Inovasi - LIPI

NET 12

\title{
PERANCANGAN PROGRAM GAME PC HACK \& SLASH BERBASIS MULTIMEDIA MENGGUNAKAN UNITY 3D
}

\author{
Darmawan Napitupulu* \\ *Pusat Penelitian Sistem Mutu dan Teknologi Pengujian - LIPI \\ *Fakultas Ilmu Komputer Universitas Borobudur
}

darwan.na70@gmail.com

\begin{abstract}
Abstrak. Perkembangan game terjadi di awal tahun 1990 di mana perkembangannya begitu pesat bahkan lebih banyak konsumerisasi daripada pengembangannya khususnya di Indonesia. Bisa dilihat dari banyaknya console game yang bermunculan dimana pengembang kebanyakan dari bagian Amerika, Eropa dan Asia. Perkembangan game diikuti juga dengan maraknya Game Engine atau Game Creator yang dapat digunakan untuk membangun, merancang dan mengembangkan game, salah satunya adalah unity 3D. Tujuan dari penelitian ini adalah merancang sebuah program game dengan menggunakan game engine unity 3D. Metode pengumpulan data meliputi studi pustaka atau literatur terkait model pengembangan games sedangkan metode perancangan meliputi pembentukan elemen elemen game dari teks, tombol, gambar, maupun animasi serta penggabungan elemen ActionScript ke dalam gambar-gambar pada game. Unity 3D dipilih karena kemampuannya menciptakan animasi yang dinamis dengan adanya fasilitas action script sehingga pembuatan game PC hack \& slash ini menjadi lebih mudah. Game PC Hack \& Slash ini dibuat untuk memecahkan kebuntuan opini yan berkembang di kalangan masyarakat bahwa proses pembuatan game sangat sulit khususnya bagi orang awam. Oleh karena itu penelitian ini bertujuan agar orang dapat mengerti teknik-teknik pembuatan game dan action script saja yang umumnya digunakan dalam software Unity 3D sehingga dapat mendorong lebih banyak jumlah game buatan lokal. Hasil dari penelitian ini berupa program Game PC Hack \& Slash yang berisi suatu karakter yang bertemu dengan musuhnya, sehingga karakter tersebut harus menghancurkannya. Karena apabila tidak dihancurkan player tidak akan dapat meneruskan ke stage berikutnya. Juga di dalam game di berikan item-item atau bonus yang dapat memulihkan Health bar player agar dapat terus melawan musuhnya.
\end{abstract}

Kata Kunci : Game, Unity 3D, action script, animasi, Hack \& Slash 
Pusat Inovasi - LIPI

\section{PENDAHULUAN}

Seiring berjalannya waktu hingga telah memasuki abad ke-21 ini, tekhnologi computer semakin hari semakin banyak mempengaruhi roda kehidupan manusia di dunia, tidak hanya dari kalangan akademik dan pemerintahan saja tetapi juga dari kalangan yang sebelumnya belum mengenal apa pentingnya teknologi computer. Salah satu kegiatan yang berl\&askan teknologi komputer adalah multimedia.Jika dilihat dari data statistic tentang suatu perkembangan, maka dapat dilihat suatu lonjakan yang luar biasa mengenai penggunaan multimedia di dunia dari masa ke masa. Hal ini berdampak pada gaya kehidupan yang lebih modern dan dinamis. Sejalan dengan perkembangan teknologi yang semakin cepat, kini paketpaket multimedia juga menawarkan perpaduan teks, grafik, animasi, bahkan game.Itu terjadi di awal 1990. Dengan perkembangan tersebut game-game engine pun bermunculan. Game engine atau game creator ini memberikan kemudahan-kemudahan dalam pembuatan dan pengembangan game. Dari begitu banyaknya game-game engine yang bermunculan salah satunya nya adalah Unity 3D dimana engine ini memberikan keluasan dan kemudahan dalam penggunaan, pembuatan dan pengembangan game. Unity 3D memberikan fasilitas-fasilitas yang memungkinkan pemula yang awalnya tidak mengerti tentang bahasa pemrograman, design, dan lain sebagainya dapat mengerti dan mungkin bisa menjadi ahli dalam pemrograman dan pembuatan game. Dan juga Unity merupakan engine yang mempunyai tools yang terintegrasi. Unity bukan saja merupakan game engine atau game creator tetapi Unity juga merupakan Editor dibandingkan dengan beberapa software lama yang sejenis seperti flash, rpgmaker, dan engineengine lainnya.

Dan sangat disayangkan dengan bermunculannya engine-engine tersebut dan perkembangan game yang sangat pesat, di Indonesia hanya menjadi konsumen saja. Terbukti dengan banyak nya perusahaan pengembangan game di Amerika, Eropa, dan Asia. Dimana bisnis dan industry pengembangan game ini sudah menjadi suatu hal yang menjanjikan. Berdasarkan hal yang diuraikan, dalam penelitian ini akan dirancang GamePC Hack \& Slash dengan menggunakan perangkat lunak Unity 3D.

\section{Game}

Game adalah suatu permainan yang terdiri dari beberapa karakter dan objek. Karakter dan objek ini biasanya digerakkan dengan bahsa program, dengan tujuan agar bias menciptakan suatu pergerakkan atau perubahan. Dalam beberapa game pengguna dapat mengkontrol langsung pergerakan dari game tersebut, tetapi ada juga game yang telah di beri suatu kecerdasan buatan dalam merespon pergerakannya sendiri, sehingga seolah-olah game itu dapat berpikir sendiri, salah satu contoh game yang telah di beri 
kecerdasan buatan adalah game catur.Memainkan game pada computer sangatlah menyenangkan namun demikian akan lebih menyenangkan bila dapat membuat game sendiri dan membiarkan orang lain memainkannya. Akan tetapi membuat game tidaklah mudah beberapa game komersial misalnya, dibuat dan dikembangkan oleh banyak orang dengan keahlian pemrograman yang tinggi dan dibuat dengan biaya yang relative besar. Meskipun untuk membuat game di katakana sangat rumit, namun game sederhana dapat di buat dengan cara yang mudah. Unity 3D, dibantu dengan action script-nya dapat untuk membuat game.

\section{Unity 3D}

Salah satu jenis aplikasi untuk membuat game yang sedang di gemari saat ini adalah membuat aplikasi game dengan Unity 3D. dengan menggunakan Unity 3D ini tidak hanya mudah dalam menggunakan atau mengerjakan suatu pekerjaaan, tetapi aplikasi Unity 3D ini juga dapat bekerja dengan aplikasi lainnya yang dapat menciptakan terbentuknya sebuah animasi dan game.Unity juga dapat digunakan untuk membuat movie yang interaktif. Maksudnya, gerakan atau aksi yang akan dilakukan animasi tergantung reaksi atau perintah atau masukan yang di berikan oleh pemakainya. Perintah itu dapat dimasukkan dengan mengetikkan masukan dengan keyboard maupun menggerakkan mouse sehingga mampu mengaktifkan perintah pengaktifan program lain untuk menggerakkan objek, memasukkan dan menampilkan informasi atau program lain. Unity 3D juga bisa di aplikasikan atau di kombinasikan dengan berbagai macam aplikasi design 3D untuk membangun karakter 3 Dimensi, seperti Blender, Maya, 3Ds Max, dan aplikasi-aplikasi design lainnya. Unity 3d sendiri di bangun pada tahun 2004 oleh David Helgason (CEO), Nicholas Francis (CCO), dan Joachim Ante (CTO) di Copenhagen, Denmark. Setelah game pertama mereka GooBall, gagal lagi dalam meraih sukses, ketiganya menyadari nilai sebuah engine dan tool dalam sebuah pengembangan game dan berencana untuk membuat sebuah engine yang dapat di gunakan oleh semua dengan harga terjangkau. Unity 3d technologies mendapat bantuan dana dari Sequoia Capital, WestSummit Capital, \& IGlobe Partners. Unity sekarang digunakan oleh 53.1\% developers (termasuk mobile game developers) dengan ratusan game yang dirilis baik untuk IOS maupun \&roid. Pada tahun 2009, unity mulai meluncurkan produk mereka secara gratis.Jumlah developer yang mendaftar melonjak drastic sejak pengumuman tersebut. Pada april 2012, unity mencapai popularitas yang sangat tinggi dengan lebih dari 1 juta developer. Unity sangat mampu melihat berbagai peluang \& perubahan. Hal inilah yang menjadikannya sebagai game engine “termurah” yang paling banyak digunakan oleh seluruh orang didunia. Ingat,unity bias di gunakan untuk perorangan dan tidak selalu harus digunakan oleh sebuah studio game yang berjumlah ratusan orang. Tampaknya, demokrasi 
yang diusung sebagai slogan unity memang benar adanya, apalagi semenjak dirilisnya unity dengan lisensi free.

\section{METODE PENELITIAN}

Metode yang digunakan dalam penelitian ini terdiri dari :

1. Metode Pengumpulan Data dengan Studi Pustaka yang dilakukan untuk memperoleh berbagai informasi yang terkait teknik pembuatan game dari berbagai jurnal, buku, majalah, tabloid komputer, sumber-sumber lainnya di Internet.

2. Metode Perancangan dalam pembuatan game berbasis multimedia yang digunakan dalam penelitian ini adalah :

- Perancangan bentuk tampilan game dan navigasinya.

- Pembentukan elemen, mengatur serta merangkai tiap-tiap elemen game dari teks, tombol, gambar, dan animasi.

- Penggabungan dan mengorganisasikan elemen ActionScript ke dalam gambar-gambar pada game.

\section{a. Rancangan Pembuatan Karakter dan Obyek}

Dalam pembuatan game selalu muncul suatu karakter yaitu karakter pemain dan karakter musuh. Ketika game tersebut dimainkan maka karakter-karakter tersebut dibuat bergerak agar permainan menjadi menarik. Didalam Unity, karakter merupakan suatu objek yang harus dikonversi menjadi suatu symbol. Karakter tersebut dapat dibuat sendiri dengan program design yang mensuport Unity atau mendownload yang ada didalam website Unity atau mengimport file buatan kita yang telah kita bangun dengan program design.Pembuatan karakter dapat mengimport dari 3D Studio MAX atau membuat langsung dengan Unity sendiri. Pembuatan karakter dengan menggunakan 3D Studio max mempunyai tekhnik pemodelan sendiri yaitu dengan tekhnik hair \& fur, tekhnik real, dan tekhnik bone \& biped. Metode pemodelan menggunakan dua metode yaitu metode pemodelan polygan dan juga NURBS. Karakter biasanya di beri pergerakan-pergerakan di mana pergerakan tersebut mempunyai tekhnik pemodelan yaitu tekhnik bone dan biped. Bone dan biped di gunakan agar object yang dibuat menjadi karakter dapat bergerak. Bone dan biped ini yang nantinya akan di rendeer menggunakan mental ray yang telah di sediakan di dalam 3D Studio MAX. Me-render di lakukan agar pergerakan karakter menjadi tampak 
Pusat Inovasi - LIPI

nyata seperti berlari, berjalan, mumukul, atau terjatuh. Membuat pergerakan pada karakter juga bisa di lakukan dengan cara pemberian action script atau juga dengan bantuan windows kinect yang terhubung ke komputer dan software 3D Studio MAX.

\section{b. Suara}

Suara di dalam game di bagi menjadi dua bagian yaknisuara efek dan suara music. Suara efek (Sound effect) muncul pada game ketika terdapat suatu kejadian tertentu seperti pada saat terpukul, terjatuh, kalah, dan kejadian-kejadian lainnya. Suara music (BGM) muncul sepanjang permainan, karena music berbeda dari efek suara. Music muncul, baik saat pembukaan di mulai dan pada saat penutupan game (Game Over). Musik atau suara ini di buat agar game lebih menarik dan ada efek tertentu ketika kita memainkan game. Musik juga merupakan salah satu bagian yang harus ada pada setiap game.

\section{c. Rancangan Scene}

Scene merupakan jendela umum dari tampilan suatu aplikasi pada layer. Pada scene di gambarkan elemen yang akan tampil pada jendela scene seperti letak, latar, warna background, animasi, teks, posisi tombol dan gambar.

Scene di susun secara berurutan dari mulai pembukaan sampai penutup dengan mengikuti rancangan struktur. Sehingga kesalahan pada rancangan program tidak terjadi dan dapat perbaiki.

\section{d. Pembuatan karakter dengan Import File}

Unity dapat mengimport beberapa file gambar seperti maya, 3D Studio MAX, blender, dan engine design lainnya. Mengimport file gambar ke dalam Unity tidak semua ekstensi file dapat di import ke dalam Unity agar tidak menimpa object yang telah ada di dalam Unity. Hal ini di buat agar tidak ada terjadinya bug atau menembus object lain. File yang dapat di import ke Unity antara lain adalah file berekstensi FBX. Mengimport file gambar ke dalam Unity sangatlah mudah. Karena Unity memberikan kemudahan bagi pengguna atau user.

\section{HASIL DAN PEMBAHASAN}

Implementasi sistem merupakan prosedur yang akan dilakukan untuk menyelesaikan rancangan sistem, dan menguji kemampuan sistem. Tujuan dari implementasi sistem adalah menguji dan mendokumentasikan prosedur-prosedur yang dirancang dalam pembuatan game pc hack \& slash. Selain itu memperhitungkan apakah sistem yang dirancang sesuai dengan yang di sebutkan. Setelah sistem terimplementasikan, maka yang harus dilakukan adalah memeliharanya agar tetap berjalan sesuai dengan fungsi dasar dari sistem tersebut. Bahkan jika memungkinkan, sistem yang telah berjalan tersebut dapat 
Pusat Inovasi - LIPI

dikembangkan menjadi lebih baik dari sebelumnya. Tampilan dari progam game PC yang telah di rancang oleh penulis dapat dilihat pada gambar yang akan di tampilkan berikut ini :

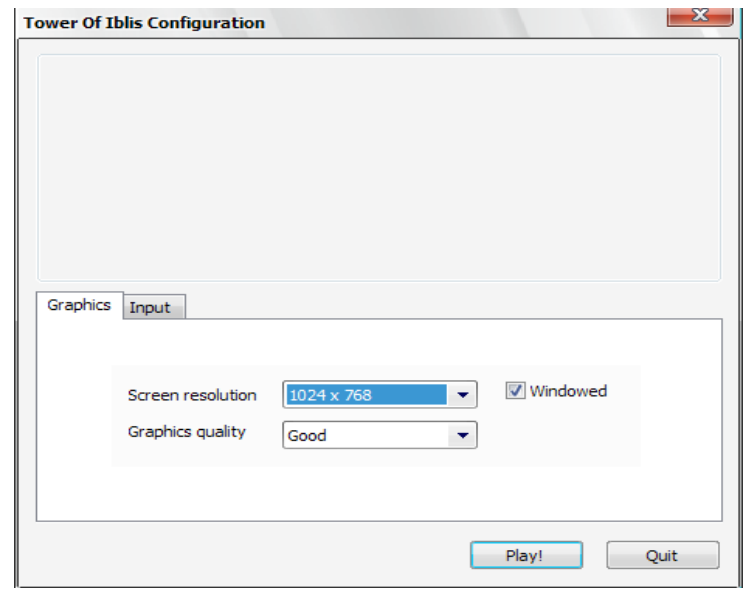

Gambar 4.1 Configuration Graphics

Pada gambar 4.1 Sebelum masuk ke dalam system program game user terlebih dahulu harus memilih configuration yang baik bagi computer user. Yaitu graphics dan input yang sesuai dengan user gunakan. Dan jika pemilihan graphics selesai maka user akan memilih input maka akan menampilkan seperti pada gambar 4.2 :

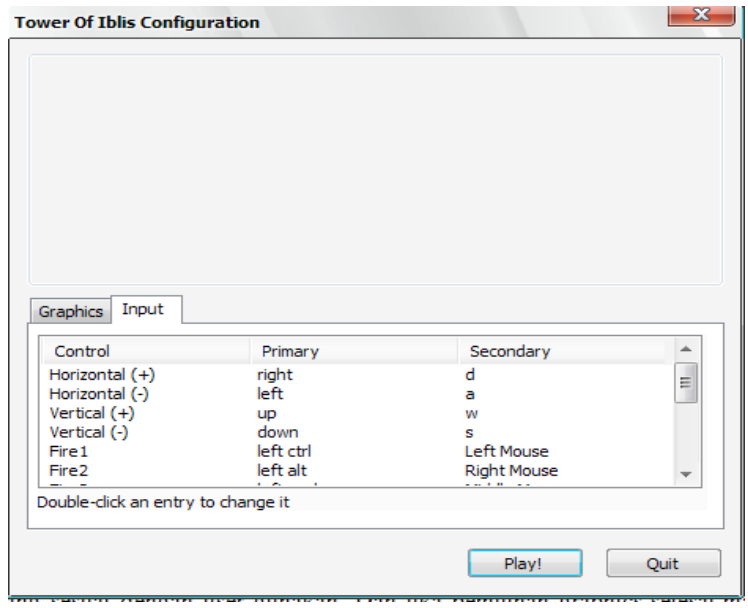

Gambar 4.2 Configuration input

Pada gambar 4.2 Configuration input merupakan kolom setting yang dimana user mensetting key atau tombol yang memudahkan dan juga memberikan kenyamanan user dalam memainkan game. Tombol- 
tombol interface ini disiapkan agar user bisa lebih mudah, dikarenakan kebiasan orang-orang dalam mengunakan key atau tombol-tombol keybord berbeda-beda dan juga bermacam-macam. Setelah user selesai dalam configuration maka user akan mengklik tombol play yang di mana user akan langsung bermain dan masuk kedalam game yang akan muncul seperti berikut ketika user menggunakan tombol play.

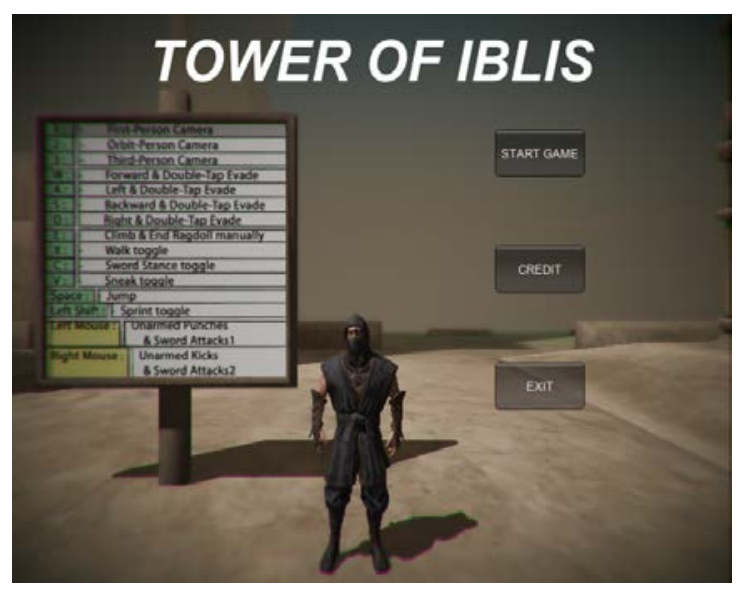

Gambar 4.3 Interface awal permainan

Pada gambar 4.3 dalam interface awal ini user dapat melihat guide atau key-key cara bermain di dalam game dan juga dapat melihat beberapa tombol dan character dalam game. Tombol-tombol yang terdapat dalam interface bisa langsung menuju start memulai permainan atau bisa mengklik credit dan tombol exit. Berikut in tampilan dari tombol credit :

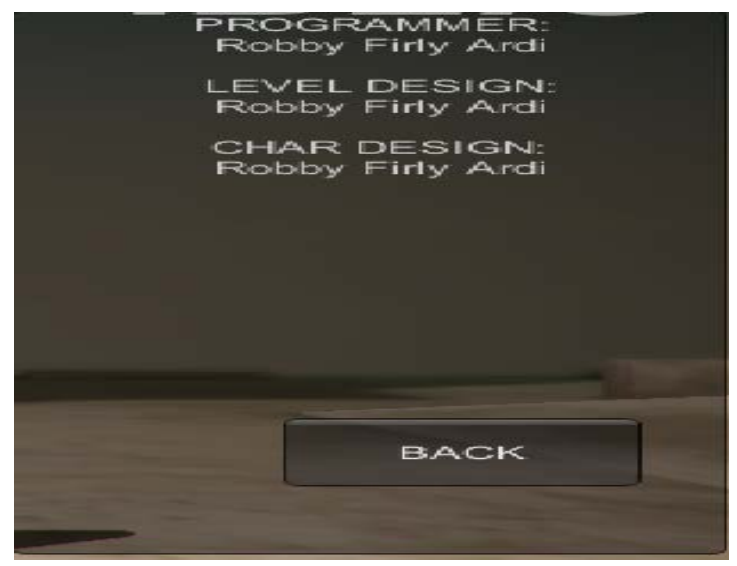

Gambar 4.4 Interface Credit

Pada gambar 4.4 Interface credit ini merupakan interface yang menunjukan siapa dan apa yang telah di kerjakan di dalam game agar dapat tercipta game. Di dalam interface credit ini penulis memberitahukan apa yang telah penulis kerjakan sampai tercipta game yang penulis buat. Setelah interface credit user 
Pusat Inovasi - LIPI

dapat langsung memainkan atau mengklik tombol exit. Gambar berikut apabila user memulai start sebagai berikut :

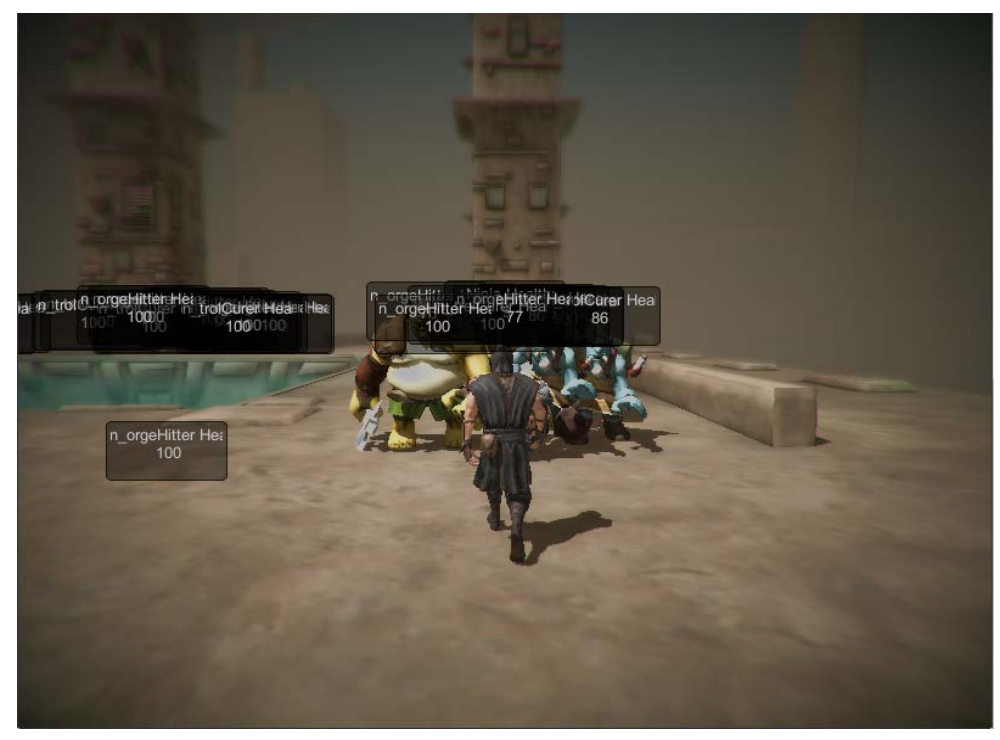

Gambar 4.5 Interface di dalam game

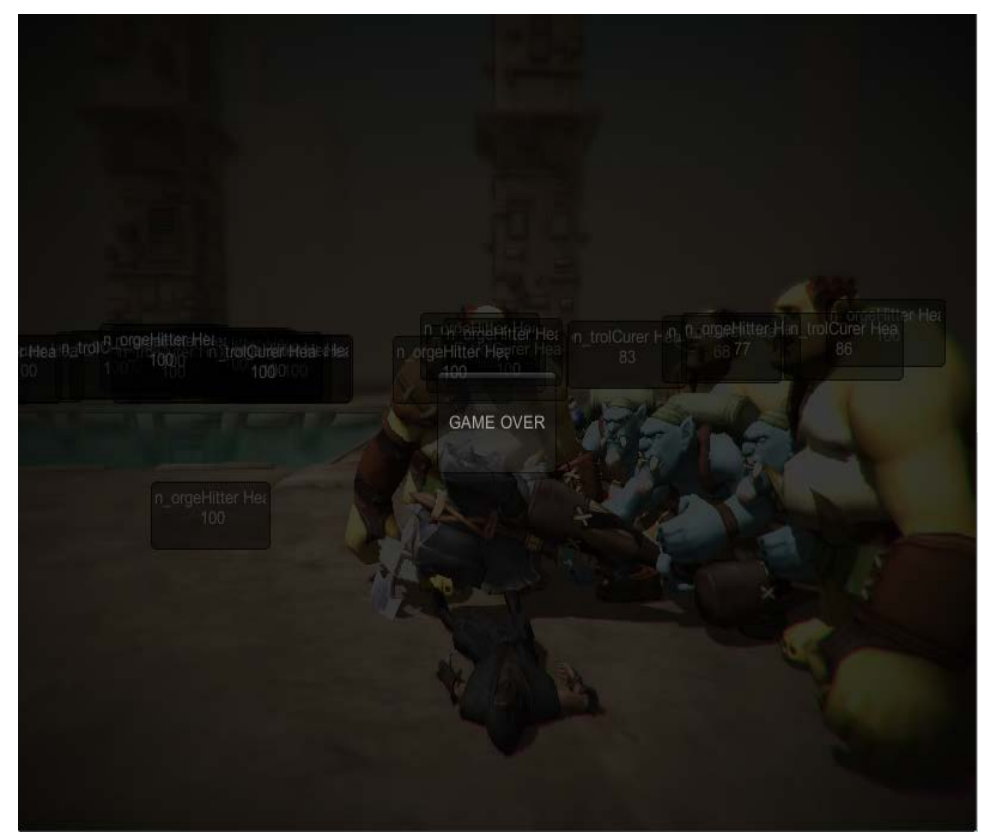

Gambar 4.6 Interface Game berakhir (Game Over)

Pada gambar 4.5 adalah interface ketika user berada di dalam game, secara umum interface ini mengacu pada permainan yang akan atau dapat user mainkan, menangkan atau kalah di dalam permainan. User juga dapat menggunakan beberapa senjata yang telah disiapkan di dalam game, dan juga dapat 
menggunakan item-item yang dapat membunuh musuh, memulihkan darah player, menambah kekuatan player dan lain-lain. Pada proses permainan di dalam game user diharuskan menyelesaikan beberapa misi yang ada di dalam game. User tidak semudah itu dapat menyelesaikan permainan di karenakan terdapat beberapa musuh yang akan menghadang player agar tidak dapat menyelesaikan permainan. Tetapi user disiapkan senjata, item dan peralatan-peralatan yang dapat membantu player untuk menyelesaikan permainan.

Pada gambar 4.6 adalah gambar ketika game berakhir dimana player telah kalah atau kehabisan Health Point, atau kehabisan Mana Point dan tidak dapat menyelesaikan misi yang telah di berikan di dalam game. Tetapi player juga dapat melanjutkan permainan dengan mengklik tombol Game Over yang berada di layar permainan kemudian kembali ke interface awal di mana user dapat memulai permainan dari awal. User juga dapat melanjutkan dan mengulang permainan dengan memulai start pada kolom interface awal. Potensi khusus yang dapat diberikan dari penelitian ini adalah memberikan kontribusi pada perkembangan pengembangan aplikasi game di Indonesia dimana seperti yang telah dijelaskan sebelumnya bahwa aplikasi game kebanyakan dihasilkan atau merupakan produk dari luar (asing). Dengan adanya penelitian ini, dapat memberikan manfaat terhadap aspek pendidikan kepada masyarakat agar tidak hanya menjadi pengguna saja tetapi dapat mengembangkan sendiri dengan metode yang telah digunakan dalam penelitian ini. Selain itu penelitian ini memberikan manfaat terhadap aspek ekonomi karena dapat mendorong munculnya usaha m\&iri khususnya dalam bidang aplikasi game developer sehingga dapat memberikan keuntungan ekonomi bagi para pelakunya. Ditambah lagi, aplikasi game yang dihasilkan dalam penelitian ini mempunyai peluang untuk memperoleh paten tentunya jika penelitian ini dapat disempurnakan lebih lanjut.

\section{KESIMPULAN DAN SARAN}

Program Game PC Hack \& Slash telah berhasil dirancang dengan menggunakan animasi yang di gabungkan dengan action script sehingga menghasilkan Aplikasi Game PC Hack \& Slash berbasis multimedia. Menerapkan Unity 3D sebagai alat bantu yang mudah digunakan dalam proses pembuatan Game.Saran berupa perancangan yang serupa tidak hanya dapat diterapkan untuk Game namun dapat dikembangkan untuk Game engine atau Game creator. Game Tools yang tersedia di pasar dapat digunakan selain Unity 3D seperti Construct 2 atau native programming seperti Visual Studio dari Microsoft dan Eclipse untuk memperkaya wawasan dalam pengembangan aplikasi khususnya game. 
Pusat Inovasi - LIPI

\section{DAFTAR PUSTAKA}

Pepen, Suherman et al. 2010. Perancangan Game Untuk Anak-Anak Petualangan Pepen Dengan Macromedia Flash, Jurnal DASI Juli, STMIK AMIKOM Yogyakarta.

Tjahjadi, M. 2014. Prototipe Game Musik Bambu Menggunakan Engine Unity 3D, Jurnal Teknik Informatika Univ.Sam Ratulangi, Vol 4, No 2.

Sihite B., Samopa, F., \& Sani, N. 2013. Pembuatan Aplikasi 3D Viewer Mobile dengan Menggunakan Teknologi Virtual Reality (Studi Kasus: Perobekan Bendera Belanda di Hotel Majapahit). Jurnal Teknik Pomits Vol 2 No 2.

Muthia \& Djunaidi. 2015. Pengembangan aplikasi pengenalan lingkungan sekitar dengan menggunakan engine Unity 3D. Majalah Ilmiah Pawiyatan Vol 22 No 3.

Hidayat, R., Purwantara, M., \& Wijaya, N. 2015. Game Ramayana Menggunakan Unity 3d Game Engine. Jurnal Sistem Informasi Vol 1 No 1.

Unity3D. 2015. Tutorial Interface \& Essentials. Sumber : https://unity3d.com/unity

Pranata, B. et al. 2015. Mudah Membuat Game dan Potensi Finansialnya dengan Unity 3D. Elex Media Komputindo, Jakarta. 